Acta Regionalia et Environmentalica 1

Nitra, Slovaca Universitas Agriculturae Nitriae, 2017, pp. 7-14

\title{
IDENTIFICATION OF DROUGHT IN WESTERN SLOVAKIA BY PALMER DROUGHT SEVERITY INDEX (PDSI)
}

\author{
Veronika ZUZULOVÁ*, Bernard ŠIŠKA \\ Slovak University of Agriculture in Nitra, Slovak Republic
}

\begin{abstract}
The paper deals with identification of drought in western Slovakia, which is based on soil-climatological data. For this purpose, three sites were chosen: Bratislava, Pieštany and Hurbanovo, situated on the Danubian Lowland. The Palmer Drought Severity Index (PDSI) was calculated on monthly basis for time series 1981-2010, 2021-2050 and 2071-2100. There were determined the driest periods by percentage of dry months for each site. The driest period in Bratislava and Hurbanovo was in the first evaluated time series. In Pieštany we can expect, that the second time series will be the driest. Linear trend of drying area will be revealed in period 2071-2100 for all three sites. The aim of the paper is to analyze and compare the occurrence of drought in temporal and spatial dimensions on the west part of Slovakia.
\end{abstract}

Keywords: drought, PDSI, Western Slovakia

Change of meteorological (climatological) characteristics results in increasing frequency of drought. Drought is ordinary reccurring phenomenon, which occurs in all climatic zones from very moist ones up to very dry ones (Tallaksen, 2007). It is a temporary deflection, when precipitations are lower than standard climate normal (Klementová and Litschmann, 2011) and therefore it becomes a limiting factor for different spheres of life (Hayes et al., 1999).

Agricultural drought is defined as a state of soil moisture with a lack of water for crops (Benetin et al., 1979). The intensity and impacts of agricultural drought are affected not only by the deficit of water, but also by biological (e.g. drought-resistant crop varieties), technical (e.g. method of soil cultivation) and economic (e.g. investments in additional irrigation systems) factors (CHMI, 2016).

Drought in conditions of the Slovak Republic can be expected mostly in ecosystems of lower altitudes, it means up to $900 \mathrm{~m}$ a.s.l. However, the areas of the Tatra National Park in altitude of over 1,500 $\mathrm{m}$ a.s.l. are in a drought-safer altitudinal zone (Vido et al., 2015).

The biggest area of crop cultivation in Slovakia is the Danubian Lowland. Drought occurrence on the Danubian Lowland was reviewed in several studies. A substantial increase of dry episodes was identified during the time series from 1951 to 2007 (Škvarenina et al., 2009). Water scarcity in agriculture becomes a limiting factor of crop yields, for example for spring barley and winter wheat yields (Takáč and Šiška, 2009). Irrigation will be an important element of crop yields stabilization in the conditions of climate change.

The significant effect of drought in Slovakia is also seen in forest ecosystems. The beech forest, which belongs to the most widespread tree species of the area (Čaboun et al., 2008) responded to the drought stress after five weeks influence of meteorological drought. Then, the symptom like a lower stem circumference increment is evident (Vido et al., 2016). Other studies present physiological reactions of spruce (Kovalčíková et al., 2011) or oak forest to drought (Hlásny et al., 2011). Not only flora, but also fauna is influenced by climate changes and drought. Effect of drought expressed by SPI (Standardized Precipitation Index) and SPEI (Standardized Precipitation Evapotranspiration Index) was reflected by reduction of reproduction success of the carabid populations (Šustek and Vido, 2013).

There exist many methods of evaluation of drought, but for this article the Palmer Drought Severity Index (PDSI) was chosen. Not only climatological conditions are used for the calculation, but also pedological characteristics of a region (Alley, 1984). It was developed by Wayne C. Palmer in the 1960's (Palmer, 1965). It is standardized for different regions and time series, so it can be used for evaluation of drought in localities with various climate conditions (Dunkel, 2009).

The aim of this article is to compare the occurrence of drought between three thirty-years periods on chosen sites on the west part of Slovakia. All three sites are located on the Danubian lowland, which is and which will be the most productive region in Slovakia during the time series from 1971 to 2000 and from 2071 to 2100 for winter wheat, spring barley and corn (Nejedlík and Šiška, 2013). Input data for 1981-2010 are quantitative ones, obtained by monitoring. Input data for other two periods, 2021-2050 and 2071-2100, are modelled by GCM Arpege. 


\section{Material and methods}

The identification of drought by PDSI was conducted through the program developed by Tom Heddinghous from UNL (the University of Nebraska-Lincoln) on 15 July, 2003 (Turňa, 2014). The input data for the calculation consist of average monthly precipitation totals, average monthly air temperature, average air temperature of the whole period, latitude and available water capacity. Data of available water capacity were provided by the Soil Science and Conservation Research Institute and climatic data by the SHMI in Bratislava. There were selected three sites: Bratislava, Pieštany and Hurbanovo. Evaluation of drought was conducted during three time series, from 1981 to 2010, from 2021 to 2050 and from 2071 to 2100. Output data of PDSI were interpreted by charts based on the Palmer classification (Table 1). The linear trends were tested on the significance level $\alpha=0.05$.

Table 1 Classification based on the Palmer Drought Severity Index

\begin{tabular}{|c|c|}
\hline PDSI & Class \\
\hline$\geq 4.00$ & extremely wet \\
\hline 3.00 to 3.99 & very wet \\
\hline 2.00 to 2.99 & moderately wet \\
\hline 1.00 to 1.99 & slightly wet \\
\hline 0.50 to 0.99 & incipient wet spell \\
\hline 0.49 to -0.49 & near normal \\
\hline-0.50 to -0.99 & incipient drought \\
\hline-1.00 to -1.99 & mild drought \\
\hline-2.00 to -2.99 & moderate drought \\
\hline-3.00 to -3.99 & severe drought \\
\hline$\leq-4.00$ & extreme drought \\
\hline
\end{tabular}

\section{Results and discussion}

By putting the output data into charts for the sites and for all three time series, the following findings were identified: In Bratislava, during the period from 1981 to 2010 (Figure 1 a) the decreasing linear trend was observed. It means it was the trend of a drying
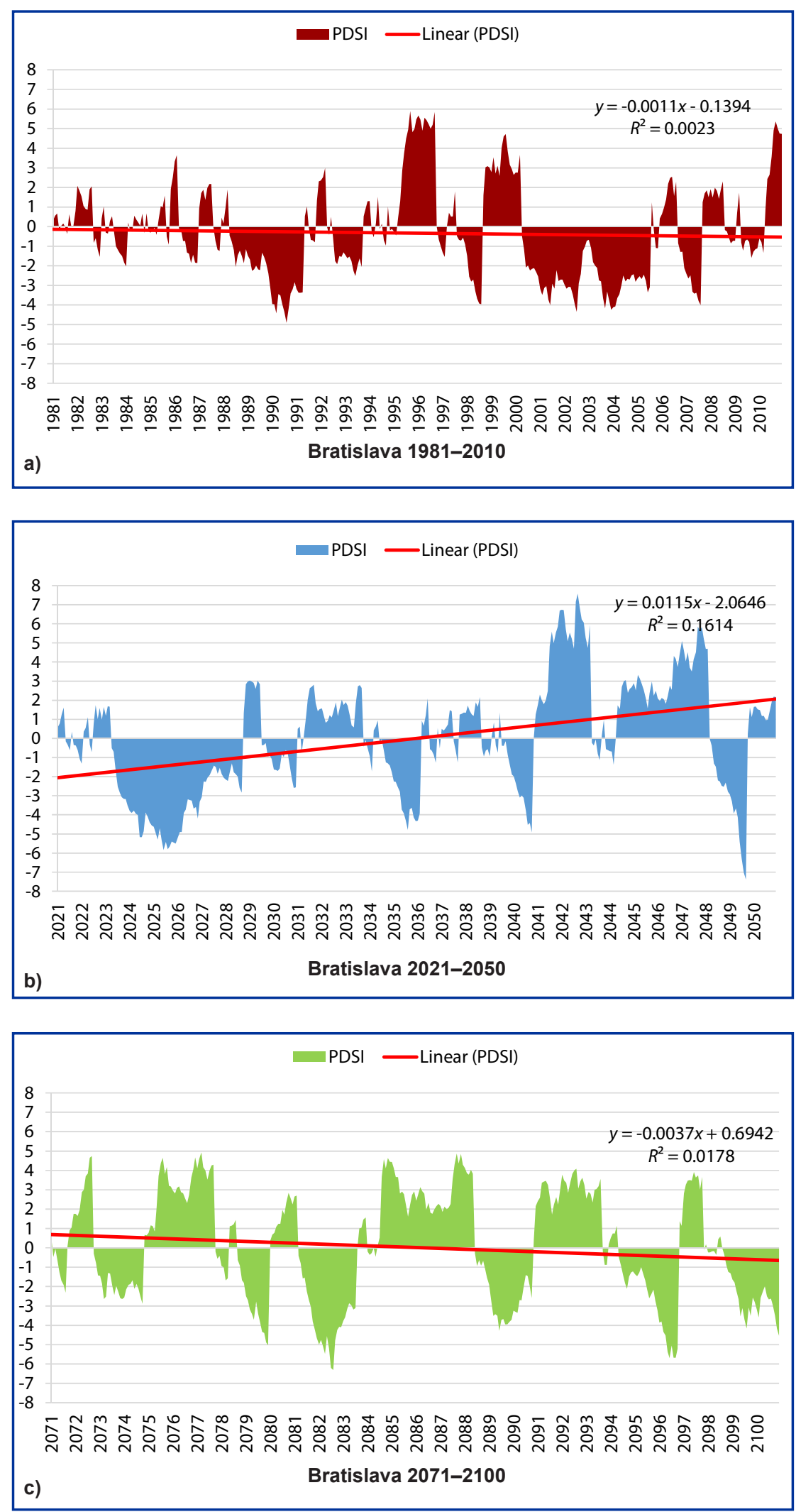

Figure 1 Monthly values of PDSI in Bratislava in the time series:

a) $1981-2010$, b) $2021-2050$, c) $2071-2100$ 
area. It was caused by the occurrence of three long-term dry seasons during whole time series in contrast to the wet seasons. There were four significant dry periods: from May 1988 to April 1991, from September 1997 to August 1998, from May 2000 to July 2005 and from September 2006 to August 2007.

There is assumed the increasing linear trend for the time series from 2021 to 2050 (Figure 1 b) as a result of a long-term dry season in the first third and two long-term wet seasons in the last third. The significant seasons of drought will be observed: from April 2023 to September 2028, from August 2034 to February 2036, from October 2039 to October 2040, from May 2048 to September 2049.

It can be expected that during the period from 2071 to 2100 (Figure 1 c), the linear trend will be decreasing. The most significant dry seasons will emerge: from September 2078 to December 2079, from April 2081 to July 2083, from July 2088 to October 2090, from June 2094 to October 2096 and from October 2098 to December 2100.

In Pieštany during the time series from 1981 to 2010 (Figure 2 a) the very slightly increasing linear trend was noticed. It was caused by extremely wet months at the end of the period. The most substantial dry seasons were: from October 1988 to October 1991, from November 1996 to August 1998, from September 2006 to August 2007. There were two significant dry seasons with duration of less than one year and they were from April 2000 to February 2001 and from March to December 2003.

The linear trend will be increasing during the period from 2021 to 2050 (Figure 2 b) according to the modelled input data. There will be three significant dry seasons: from May 2023 to March 2026, from July 2034 to September 2037 and from April 2048 to September 2049.

During the period from 2071 to 2100 (Figure $2 \mathrm{c}$ ) there is expected a slightly decreasing linear trend. This will be due to extremely dry and very dry months during last years of the period. Important seasons of drought will include months: from November 2072 to October 2074, from November 2078 to December 2079, from April
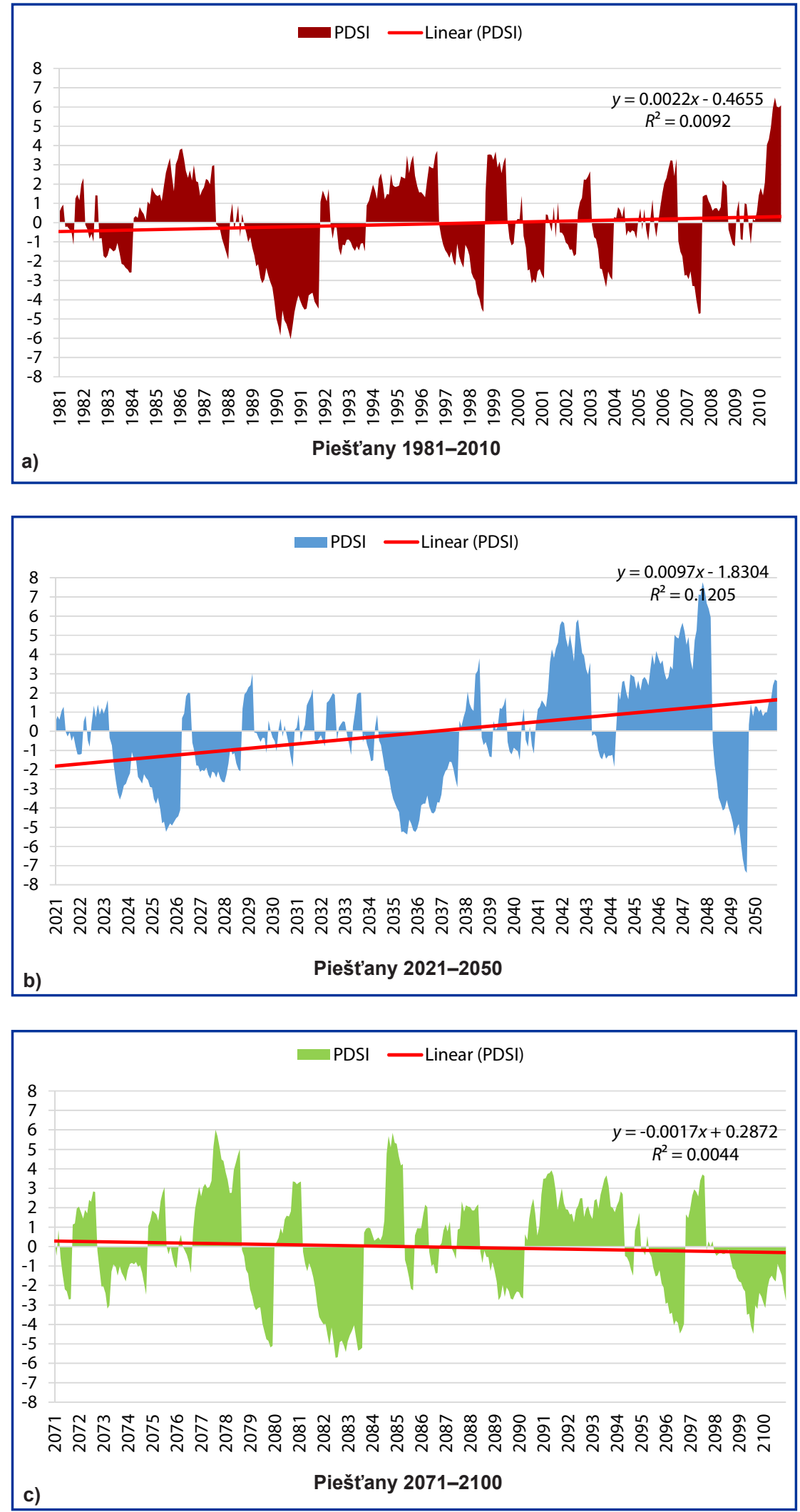

Figure 2 Monthly values of PDSI in Pieštany in the time series: a) $1981-2010$, b) $2021-2050$, c) $2071-2100$ 
2081 to August 2083, from June 2095 to October 2096 and from September 2098 to December 2100.

In Hurbanovo during the first period (Figure 3 a) the linear trend was very slightly increasing. This trend occurred because of the extremely wet year 2010. In this time series there were several significant dry seasons: from May 1982 to July 1984, from September 1989 to October 1991, from May 2000 to July 2002, from October 2006 to December 2008. There was one substantial season of drought shorter than one year and it was the season from March 2003 to January 2004.

During the time series from 2021 to 2050 (Figure 3 b) there can be expected the increasing linear trend, which will manifest due to launching of extremely wet seasons in the second half of the period. The most significant dry seasons will be: from September 2022 to September 2028, from December 2029 to November 2030, from December 2034 to December 2036, from May 2048 to September 2049.

The linear trend during the period from 2071 to 2100 (Figure 3 c) will be very slightly decreasing. The most essential seasons of drought will show up: from November 2072 to October 2074, from November 2078 to December 2079, from May 2081 to June 2084, from June 2088 to October 2090, from May 2095 to September 2096 and from September 2098 to October 2099.

The mild drought category was the most represented one in Bratislava during the time series from 1981 to 2010 (Figure 4 a). The percentage of this category was $16 \%$. The percentage of the extremely dry months was $3 \%$. Share of all dry months from incipient drought to extreme drought was $53 \%$.

It can be assumed that the mild drought category will be the most represented one with $17 \%$ during the period from 2021 to 2050 (Figure 4 b). The share of the extremely dry months in comparison with the previous period will increase to $10 \%$. Dry months from incipient drought to extreme drought will account for $44 \%$.

It can be expected that the mild drought category will be the most represented one during the period from 2071 to 2100 (Figure 4 c) and the
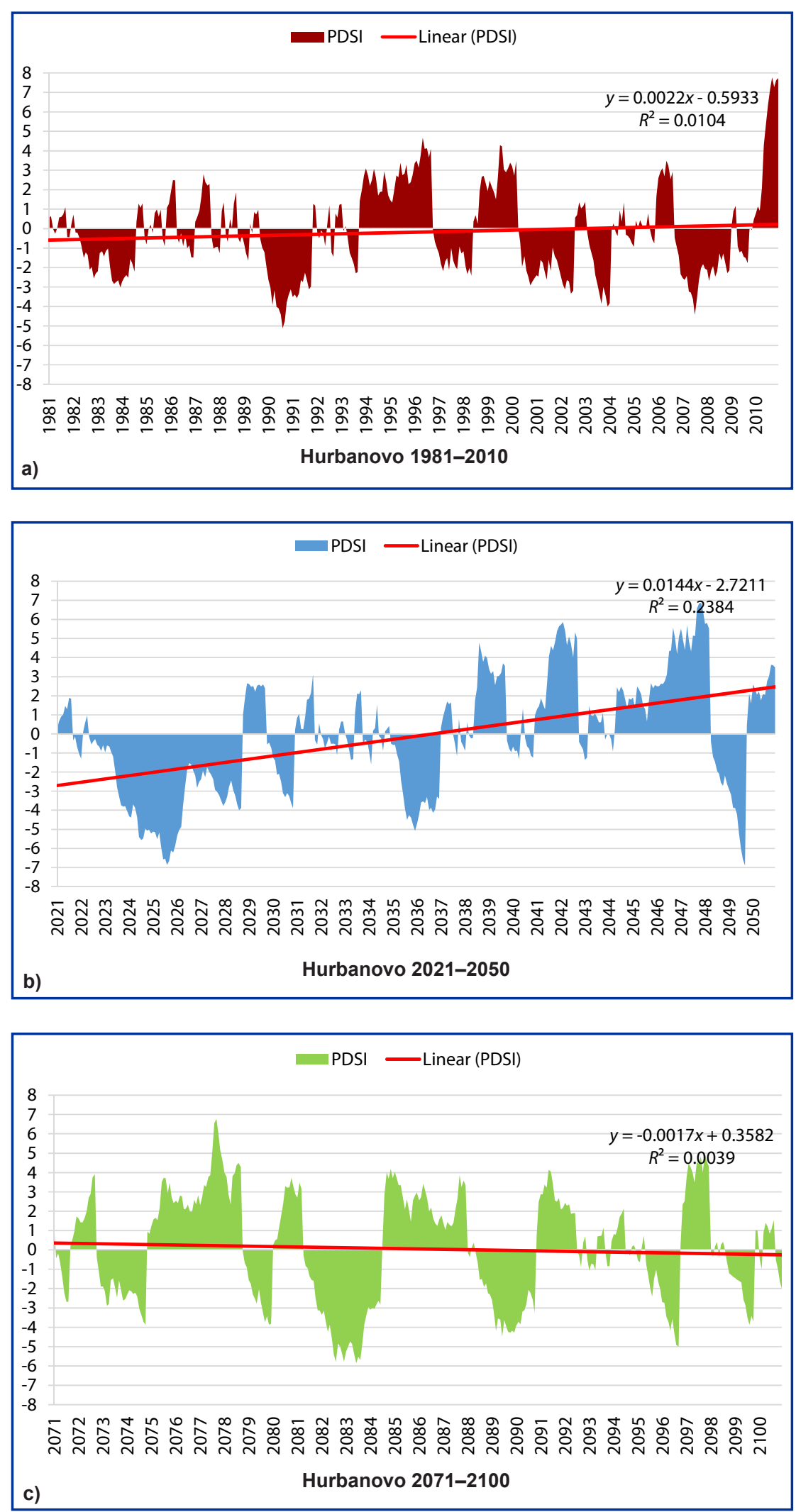

Figure 3 Monthly values of PDSI in Hurbanovo in the time series: a) 1981-2010, b) 2021-2050, c) 2071-2100 
share will be $14 \%$. The extremely dry months will be represented by $8 \%$. The whole share of dry months will reach $45 \%$.

The mild drought category was the most represented one with the share of $17 \%$ in Pieštany during the period from 1981 to 2010 (Figure 5 a). The share of the extremely dry months was $7 \%$. Dry months from incipient drought to extreme drought were represented by $44 \%$.

According to the modelled data, the near normal category will be the most represented one during the time series from 2021 to 2050 (Figure 6 b) with $13 \%$. The share of the extremely dry months will be higher than in the previous period. It will reach $11 \%$. The sum of percentages of categories from incipient drought to extreme drought will represent $47 \%$.

During the last period from 2071 to 2100 (Figure $5 \mathrm{c}$ ) the categories of mild drought and slightly wet months will be the most represented ones with the same share, which will be $13 \%$. The share of the extremely dry months will decrease to $8 \%$ compared with the previous time series. All dry months from incipient drought to extreme drought will cover $44 \%$.

There were three categories with the same percentage and they were the most represented categories with the share of $16 \%$ during the period from 1981 to 2010 in Hurbanovo (Figure 6 a). Into these categories there were included the periods of near normal, mild drought and moderate drought. The extremely dry months amounted to $2 \%$. The shares of months classified to categories from incipient drought to extreme drought were $48 \%$.

The near normal category will be the most represented one with 13\% during the time series from 2021 to 2050 (Figure 6 b). Extreme drought will cover $11 \%$ months of the period. It means that the percentage of extreme drought will increase in comparison to the previous period. The whole share of dry months will be $45 \%$.

The moderately wet months will prevail with the share of $14 \%$ during the period from 2071 to 2100 (Figure 6 c). The share of extremely dry months will acquire $8 \%$. The percentage of dry months from category incipient drought to extreme drought will decrease to $44 \%$.
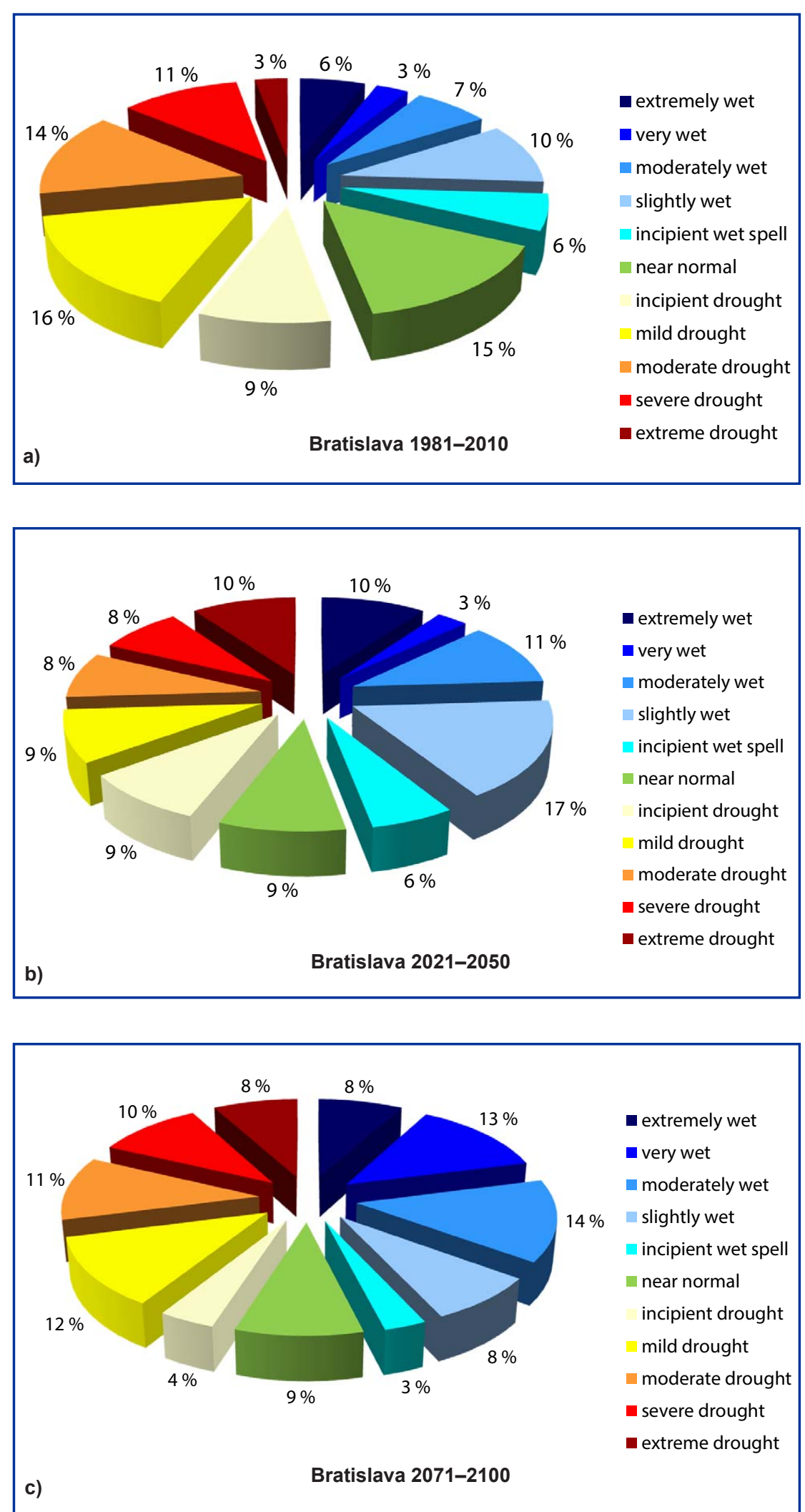

Figure 4 Percentage of monthly values of PDSI in each category according to the Palmer classification in Bratislava in the time series: a) $1981-2010$, b) $2021-2050$, c) $2071-2100$ 
By comparison of linear trends among the sites and the time series it can be concluded that the linear trend of drying area (decreasing linear trend) will be shown on all sites during the modelled period from 2071 to 2100 . However, the trend was significant only for Bratislava with the correlation coefficient $R^{2}=0.0178$, which is still small. Contrariwise, the linear trend tending to the humid climate will be manifested during the modelled period from 2021 to 2050. The reason is that there will be increased occurrence of very wet and extremely wet months during the second half and during the last third of the time series. The correlation coefficient for Bratislava was $R^{2}=$ 0.1614 , for Pieštany $R^{2}=0.1205$ and for Hurbanovo $R^{2}=0.2384$. All trends were statistically significant. The variability of the linear trends among the sites was observed throughout the period from 1981 to 2010. The decreasing linear trend in Bratislava was caused by the significant share of the extremely dry months during the whole period. The increasing linear trends were identified in Pieštany and Hurbanovo. It was due to the incidence of extremely wet months in the last year and lower share of very wet and extremely wet months in contrast with Bratislava. The linear trends during the period 1981-2010 were not significant and correlation coefficients were very small.

The driest period, which would be communal for the sites, cannot be clearly determined according to the percentage of months in categories from incipient drought to extreme drought. The period from 1981 to 2010 was the driest period in Bratislava and Hurbanovo. It can be expected that the driest period in Pieštany will be from 2021 to 2050. However, we can review that the extremely dry months will be the most represented ones during the time series from 2021 to 2050.

The results of dry seasons in Hurbanovo proved partial compliance with results from other case studies, which were focused on evaluation of drought on this site. Patassiová et al. (2003) reported that the driest year was 1990 and other dry years were 1991, 1992, 1993, 1997, 1998 and 2000, which is the same outcome as ours.
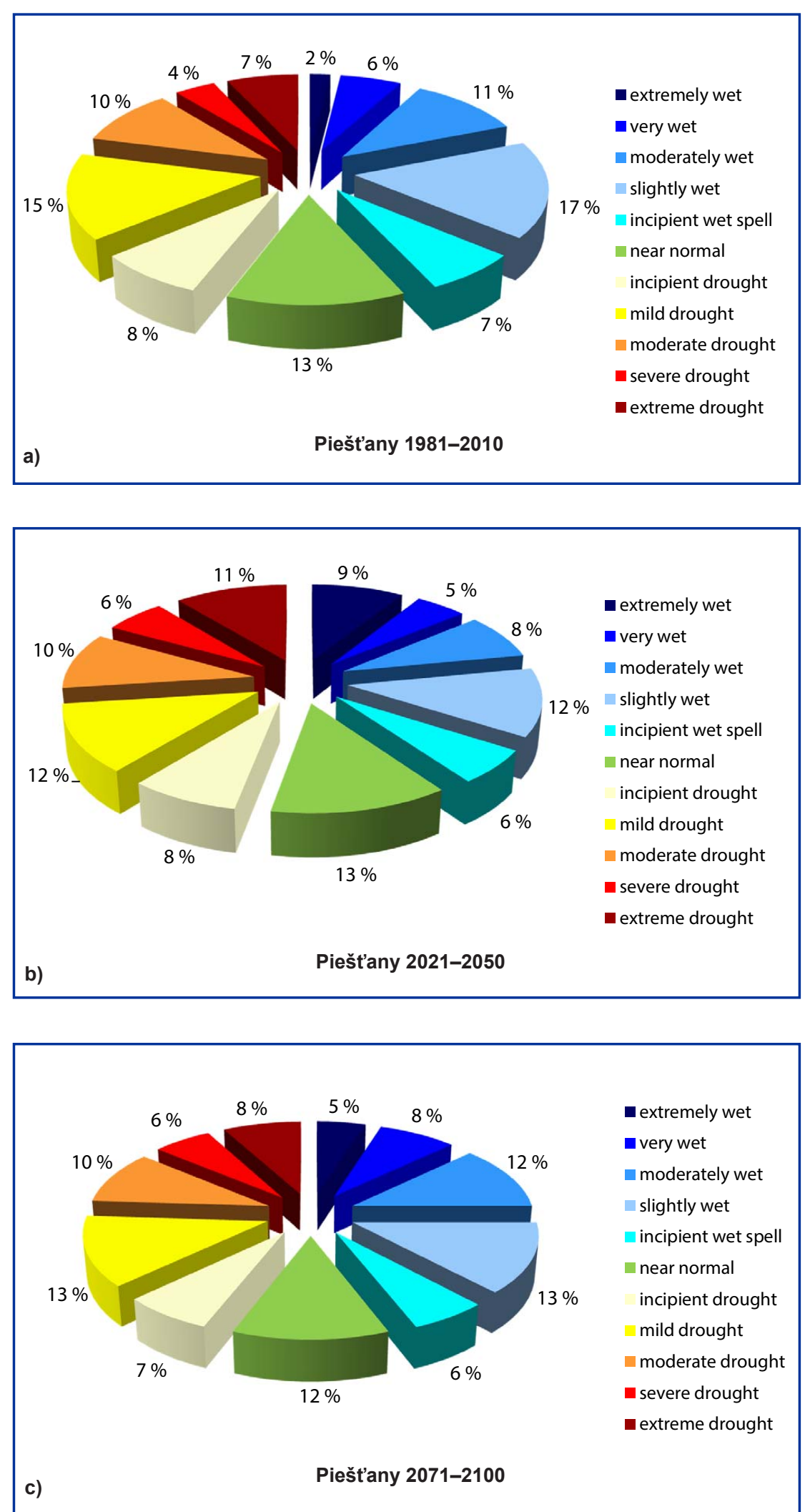

Figure 5 Percentage of monthly values of PDSI in each category according to the Palmer classification in Pieštany in the time series: a) 1981-2010, b) 2021-2050, c) 2071-2100 
There were five extremely dry months observed in 1990. It was from May to September and the minimum value of PDSI was -5.12. Also Litschmann et al. (2002) figured out that the year 1990 was the driest one of the period from 1876 to 2000 , but the minimum value of PDSI was -6.0. The linear trend was evaluated in one of the studies (Patassiová et al., 2003). The authors reported that the linear trend tended to arid climate during the time series from 1961 to 2000. Our results showed that the linear trend tended to humid climate, but in the time series from 1981 to 2010 . The variability between the results of different studies is probably due to dissimilar time series, because one of the input data is average air temperature of the whole period.

It is not appropriate to compare results from other localities because input data include latitude and available water capacity of the site.

\section{Conclusion}

The article was focused on evaluation of drought by PDSI on sites Bratislava, Pieštany and Hurbanovo during the three time series (1981-2010, 20212050, 2071-2100). According to the values of PDSI, linear trends were evaluated and compared between the sites and each time series. Then, dry seasons were defined and the percentages of dry months were calculated. However, it is necessary to be cautious, when linear trends are interpreted. If the extreme values appear at the beginning or at the end of the period, they can radically affect the trends. In this case, the year 2010, which was extremely wet, could cause increasing linear trends, that prevailed during the period from 1981 to 2010.

\section{Acknowledgement}

This work was supported by the Slovak Grant Agency for Science (VEGA) Grant No. 1/0767/17 Response of ecosystem services of grape growing country to climate change regional impact change of function to adaptation potential.
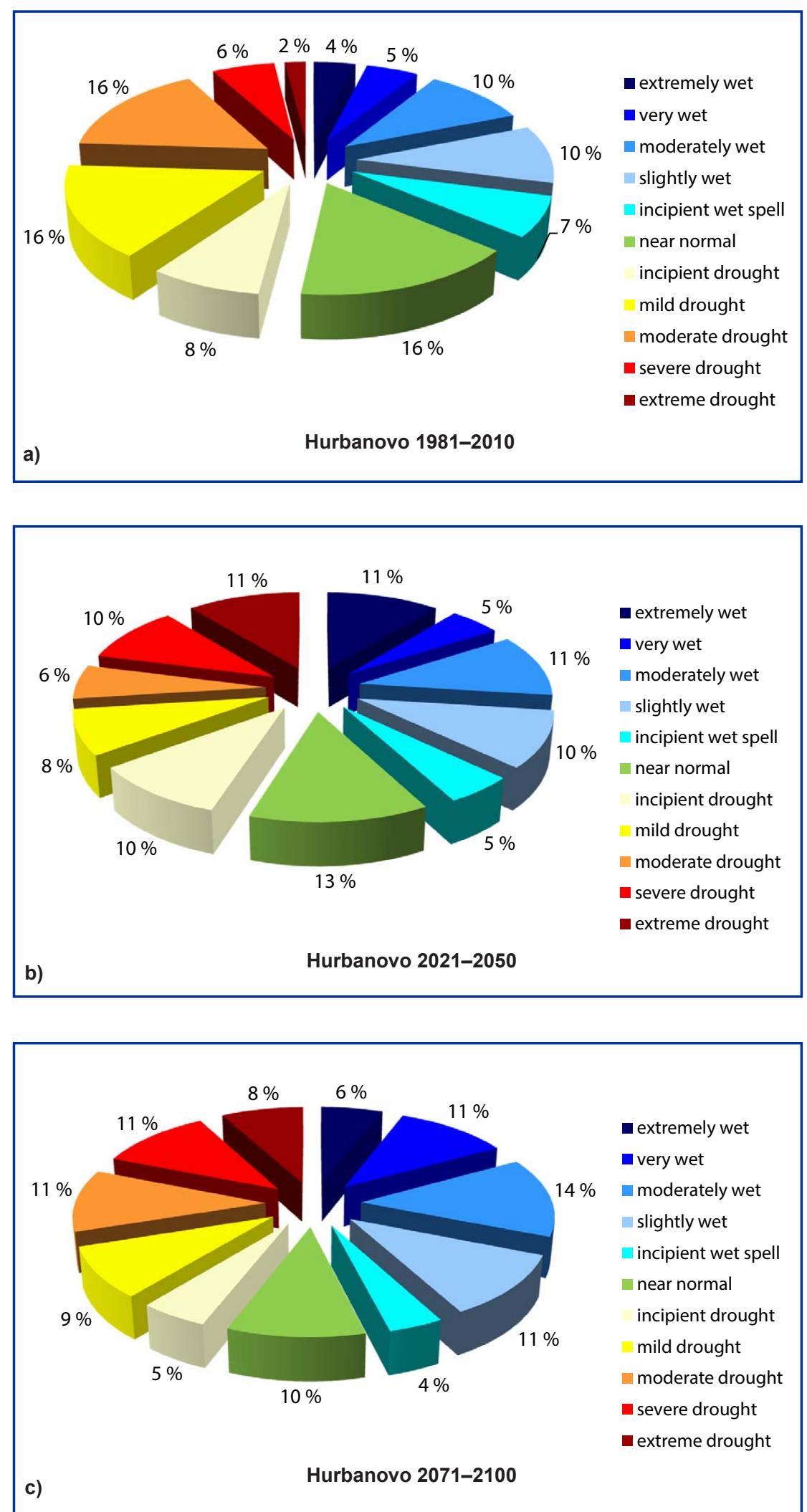

Figure 6 Percentage of monthly values of PDSI in each category according to the Palmer classification in Hurbanovo in the time series: a) 1981-2010, b) 2021-2050, c) 2071-2100 


\section{References}

ALLEY, W. M. 1984. The Palmer Drought Severity Index: Limitations and Assumptions. In Journal of Climate and Applied Meteorology [online], vol. 23, 1984, no. 7 [Retrieved 2016-04-10]. Retrieved from: http://journals.ametsoc.org/doi/pdf/10.1175/1520-0450\%281 984\%29023\%3C1100\%3ATPDSIL\%3E2.0.CO\%3B2

BENETIN, J. - FÍDLER, J. - HRABAL, A. - RAUČINA, Š. 1979. Závlahy. Bratislava : Príroda, 1979, 544 p.

CHMI. 2016. Sucho [online], [Retrieved 2016-10-28]. Retrieved from: http://portal.chmi.cz/files/portal/docs/meteo/ok/SUCHO/ New_Definice_sucha.html

ČABOUN, V. - HLÁSNY, T. - IŠTOŇA, J. - JANKOVIČ, J. - KAŠTIER, P. - KOVALČÍK, M. - KUNCA, A. - LONGAUER, R. - MORAVČÍK, M. - PAVLENDA, P. - PRIWITZER, T. - RÉH, R. - SUŠKOVÁ, M. SVITOK, R. - ŠTEFANČÍK, I. - TUTKA, J. - VLADOVIČ, J. - ZEMKO, M. - ZÚBRIK, M. 2008. Lesy a lesníctvo na Slovensku. Propagačnoinformačná publikácia o význame lesov, možnostiach jeho využitia a o hospodárení v lesoch Slovenska pre širokú i odbornú verejnost', 2008, 83 p. ISBN 978-80-8093-063-9.

DUNKEL, Z. 2009. Brief surveying and discussing of drought indices used in agricultural meteorology. In Időjárás: Quarterly Journal of the Hungarian Meteorological Service, vol. 113, 2009, no. 1-2, pp. 23-37.

HAYES, M. J. - SVOBODA, M. D. - WILHITE, D. A. - VANYARKO, O. V. 1999. Monitoring the 1996 Drought Using the Standardized Precipitation Index. In Bulletin of the American Meteorologic Society, vol. 80, 1999, pp. 429-438.

HLÁSNY, T. - BUCHA, T. - KONÔPKA, M. - KOREŇ, M. - BARKA, I. 2011. Hodnotenie vplyvu sucha na porasty duba cerového $s$ využitím satelitných záznamov MODIS. In STŘELCOVÁ, K. - SITKOVÁ, Z. KURJAK, D. - KMEŤ, J. (eds.). Stres suchom a lesné porasty : aktuálny stav a výsledky výskumu. Zvolen : TU, 2011, pp. 233-238. ISBN 978-80-228-2233-6.

KLEMENTOVÁ, E. - LITSCHMANN, T. 2011. Výsledky hodnotenia sucha v oblasti Hurbanova. In ROŽNOVSKÝ, J. - JANOUŠ, D. (ed). Sucho, hodnocení a predikce. Pracovní semináŕ, Brno 19. 11. 2001 [online], [Retrieved 2016-04-14]. Retrieved from: http://cbks.cz/ sucho01/Klementova.pdf

KOVALČíKOVÁ, D. - STŘELCOVÁ, K. - KURJAK, D. - DITMAROVÁ L. - BALÁŽ, P. - FRIČ, M. 2011. Fyziologická reakcia sadeníc smreka na simulované sucho. In STŘELCOVÁ, K. - SITKOVÁ, Z. - KURJAK, D. - KMEŤ, J. (eds.). Stres suchom a lesné porasty : aktuálny stav a výsledky výskumu. Zvolen : T, 2011, pp. 122-134. ISBN 978-80-228-2233-6.

LITSCHMANN, T. - KLEMENTOVÁ, E. - ROŽNOVSKÝ, J. 2002. Vyhodnocení period sucha $v$ časových řadách pražského Klementina a Hurbanova pomocí PDSI. In XIV. Česko-slovenská bioklimatologická konference, Lednice na Moravě, vol. 2, 2002, no. 4, pp. 280-289.
NEJEDLÍK, P. - ŠIŠKA, B. 2013. Climate change impacts and the adaptation options in agriculture in Slovakia. In Šiška B. et al. Environmental changes and adaptation strategies, Slovakia, Skalica [online]. [Retrieved 2016-10-25]. Retrieved from: http://www.cbks. Cz/SbornikSkalice2013/pdf/Nejedlik.pdf

PATASSIOVÁ, M. - KLEMENTOVÁ, E. - LITSCHMANN, T. - ČISTÝ, M. 2003. Výskyt sucha a analýza zrážok pri jeho výskyte $v$ jarných mesiacoch. In Acta Hydrologica Slovaca [online], vol. 3, 2003, no. 1, pp. 94-101 [Retrieved 2016-04-12]. Retrieved from: http://www. amet.cz/vyskytsucha.pdf

PALMER, W. C. 1965. Meteorologic Drought: Research Paper no. 45, Washington, D.C. : U.S. Weather Bureau, 1965, 58 p.

ŠKVARENIANA, J. - TOMLAIN, J. - HRVOL, J. - ŠKVARENINOVÁ, J. NEJEDLÍK, P. 2009. Progress in dryness and wetness parameters in altitudinal vegetation stages of West Carpathians: Time-series analysis 1951-2007. In Időjárás: Quarterly Journal of the Hungarian Meteorological Service, vol. 133, 2009, no. 1-2, pp. 47-54.

ŠUSTEK, Z. - VIDO, J. 2013. Vegetation state and extreme drought as factors determinin differentiation and succession of Carabidae communities in forests damaged by a windstorm in the High Tatra Mts. In Biologia, vol. 68, 2013, no. 6, pp. 1198-1210.

TAKÁČ, J. - ŠIŠKA, B. 2009. Climate Change Impact on Spring Barley and Winter Wheat Yields on Danubian Lowland. In STŘELCOVÁ, K. et al. (eds.): Bioclimatology and Natural Hazards, Springer, 2009, 16, pp. 283-288. ISBN 987-1-4020-8876-6 24.

TALLAKSEN, L. M. 2007. Key aspects of low flow and drought. In Book of Abstracts, International CHR-Workshop - Expert Consultation, Würzburg, Germany, 25 - 26 September 2007 [online], pp. 13-18. [Retrieved 2016-04-12]. Retrieved from: http:// www.eu-watch.org/media/default.aspx/emma/org/10001931/ $\mathrm{Key}+\mathrm{aspects}+$ of+low+flow+and+drought_abstract_ Tallaksen_31Aug07\%5B1\%5D.pdf

TURŇA, M. 2014. PDSI [e-mail]. Message for: Veronika ZUZULOVÁ. 2014-03-03 [Retrieved 2016-04-11].

VIDO, J. - STŘELCOVÁ, K. - NALEVANKOVÁ, P. - LEŠTIANSKA, A. KANDRÍK, R. - PÁSTOROVÁ, A. - ŠKVARENINA, J. - TADESSE, T. 2016. Identifying the relationships of climate and physiological responses of a beech forest using the Standardised Precipitation Index: a case study for Slovakia. In Journal of Hydrology and Hydromechanics, vol. 64, 2016, no. 3, pp. 246-251.

VIDO, J. - TADESSE, T. - ŠUSTEK, Z. - KANDRÍK, R. - HANZELOVÁ, M. - ŠKVARENINA, J. - ŠKVARENINOVÁ, J. - HAYES, M., 2015. Drought Occurrence in Central European Mountainous Region (Tatra National Park, Slovakia) within the Period 1961-2010. In Advances in Meteorology, 2015, 8 p. 